medRxiv preprint doi: https://doi.org/10.1101/2021.10.07.21264420; this version posted October $11,2021$. The copyright holder for this preprint (which was not certified by peer review) is the author/funder, who has granted medRxiv a license to display the preprint in It is made available under a CC-BY-NC-ND 4.0 International license.

\title{
No proof for retinal amyloid after oral curcumin in amyloid confirmed AD cases
}

Jurre den Haan ${ }^{1}, \mathrm{MD}$, PhD, Frederique J. Hart de Ruyter ${ }^{1}, \mathrm{MD}$, Benjamin Lochocki², PhD, Maurice A.G.M. Kroon ${ }^{3}$, PharmD, E. Marleen Kemper ${ }^{3}$, PharmD, PhD, Charlotte E. Teunissen, $\mathrm{PhD}^{4}$, Bart van Berckel, MD, PhD5 , Philip Scheltens, MD, $\mathrm{PhD}^{1}$, Jeroen J. Hoozemans, $\mathrm{PhD}^{6}$, Aleid van de Kreeke, MD, $\mathrm{PhD}^{7}$, Frank D. Verbraak, MD, $\mathrm{PhD}^{8}$, Johannes F. de Boer, $\mathrm{PhD}^{2 *}$, Femke H. Bouwman, MD, $\mathrm{PhD}^{1 *}$.

${ }^{1}$ Amsterdam UMC, location VUmc, Alzheimer Center, Neurology, Amsterdam, The Netherlands, 2 VU Amsterdam, Department of Physics, LaserLaB, The Netherlands

${ }^{3}$ Amsterdam UMC, location AMC, Department of Pharmacy and Clinical Pharmacology, Amsterdam, The Netherlands.

${ }^{4}$ Amsterdam UMC, location VUmc, Neurochemistry lab, Department of Clinical Chemistry, Amsterdam Neuroscience, Amsterdam UMC, Vrije Universiteit Amsterdam, The Netherlands

${ }^{5}$ Amsterdam UMC, location VUmc, Department of Nuclear Medicine, Amsterdam, The Netherlands

${ }^{6}$ Amsterdam UMC, location VUmc, Department of Pathology, Amsterdam Neuroscience, The Netherlands

${ }^{7}$ Amsterdam UMC, location AMC, Ophthalmology Department Amsterdam, The Netherlands ${ }^{8}$ Amsterdam UMC, location VUmc, Ophthalmology Department, Amsterdam, The Netherlands ${ }^{*}$ Equal contribution.

Corresponding author:

Femke Bouwman, MD, PhD

Alzheimer center Amsterdam, Department of Neurology

Amsterdam UMC

Mailbox 7057

1007 MB Amsterdam

The Netherlands

Phone: +31204440685

Fax: +31204448529

Email: femke.bouwman@amsterdamumc.nl 
medRxiv preprint doi: https://doi.org/10.1101/2021.10.07.21264420; this version posted October 11, 2021. The copyright holder for this preprint (which was not certified by peer review) is the author/funder, who has granted medRxiv a license to display the preprint in It is made available under a CC-BY-NC-ND 4.0 International license .

\section{Abstract}

\section{INTRODUCTION:}

Previous work showed in-vivo presence of retinal amyloid in AD patients using curcumin. We aimed to replicate these findings in an amyloid biomarker confirmed cohort.

\section{METHODS:}

Twenty-six AD patients (age $66( \pm 9), M M S E \geq 18)$ and 14 controls (age $71( \pm 12))$ used three curcumin formulations: Longvida ${ }^{\circledR}$, Theracurmin ${ }^{\circledR}$ and Novaso ${ }^{\circledR}$. Plasma levels were determined and pre- and post- curcumin retinal scans acquired using autofluorescence imaging. Images were both visually and quantitatively assessed.

\section{RESULTS:}

Visual assessment showed no difference between AD patients and controls for preand post-curcumin images. This was confirmed by quantitative analyses. Mean plasma curcumin levels were $198.7 \mathrm{nM}\left(\right.$ Longvida $\left.^{\circledR}\right), 576.6 \mathrm{nM}\left(\right.$ Theracurmin $\left.^{\circledR}\right)$ and $1605.8 \mathrm{nM}\left(\right.$ Novasol $\left.^{\circledR}\right)$.

\section{DISCUSSION:}

We found no difference in retinal focal fluorescence in an amyloid biomarker confirmed cohort of AD patients and controls, using Longvida ${ }^{\circledR}$ (previously used for this purpose) and two additional curcumin formulations yielding higher curcumin plasma levels. We therefore question the presence of retinal amyloid. 
medRxiv preprint doi: https://doi.org/10.1101/2021.10.07.21264420; this version posted October 11,2021 . The copyright holder for this preprint (which was not certified by peer review) is the author/funder, who has granted medRxiv a license to display the preprint in It is made available under a CC-BY-NC-ND 4.0 International license .

\section{Background}

Alzheimer's disease $(A D)$ research over the last decades enabled clinicians to diagnose $A D$ not only in the dementia end-stage but also in the prodromal and preclinical stages using biomarkers for amyloid, tau and neurodegeneration [1, 2]. AD pathology starts $15-20$ years before symptom onset and is reflected by change of biomarkers in the preclinical stage [1]. This time-interval provides a window of opportunity for disease modifying drugs to potentially halt disease progression towards the end stage of AD: dementia [3]. As currently used biomarkers are time consuming, expensive and/or invasive, non-invasive easily accessible biomarkers are urgently needed to diagnose $A D$ in the earliest stages, enabling timely selection of patients for trials and future medication.

The retina is an extension of the central nervous system and might provide such a biomarker. As such the retina is increasingly studied for manifestations of $A D$ as potential non-invasive AD biomarkers. For example, retinal thinning, changes in retinal vasculature and peripheral drusen have been described in AD patients [4-6]. More specifically related to AD pathology, three small studiesreported visualization of retinal amyloid beta deposits in-vivo using curcumin, a polipotent polyphenol with fluorescent properties that binds to amyloid in post-mortem brain tissue [7-9]. The presence of retinal amyloid beta deposits is however not unequivocally proven, since we and other groups could not confirm amyloid beta deposits in post mortem retinal tissue [10-14]. Moreover, curcumin is known for its low bioavailability, and while several commercially available formulations enhancing curcumin plasma levels are on the market, so far only one formulation (Longvida ${ }^{\circledR}$ ) has been reported to visualize retinal amyloid [7]. 
medRxiv preprint doi: https://doi.org/10.1101/2021.10.07.21264420; this version posted October $11,2021$. The copyright holder for this
preprint (which was not certified by peer review) is the author/funder, who has granted medRxiv a license to display the preprint in It is made available under a CC-BY-NC-ND 4.0 International license .

In the current study, we used three different curcumin formulations as labeling fluorophore. Using a targeted fluorescence approach, we aimed to visualize retinal amyloid in a well-characterized and amyloid biomarker confirmed AD cohort.

\section{Methods}

\section{Participants}

We enrolled 26 patients with AD (MMSE score $\geq 17$ ) and 14 controls from two different cohorts - the Alzheimer Dementia Cohort (ADC) and the EMIF-AD PreclinAD study. All subjects underwent extensive screening according to a standardized protocol described $[15,16]$. All patients fulfilled NIA-AA criteria of AD with amyloid biomarker confirmation through either CSF amyloid beta $1-42\left(A \beta_{42}\right)$ analysis or amyloid-PET [1]. ADC controls had subjective cognitive decline, defined as cognitive complaints without objective cognitive impairment on neuropsychological exam, no signs of neurodegeneration on neuroimaging, and absence of $A D$ pathology based on CSF biomarkers and/or amyloid-PET. Exclusion criteria for all participants were ophthalmological conditions interfering with retinal scan quality, e.g. more than moderate age related macular degeneration, diabetic retinopathy, or glaucoma. In addition, we excluded subjects with ischemic stroke and/or mild to severe white matter hyperintensities on MRI, operationalized as a Fazekas score $>2$. We excluded two AD patients; one because of problems with eye fixation due to visuoperceptive dysfunction and one because of participation in a drug trial with disease modifying drugs. We excluded two controls; one due to problems finishing the scan protocol because of dry eyes and one was found to have glaucoma. Three $A D$ patients were lost to follow up. This study was designed and conducted according 
medRxiv preprint doi: https://doi.org/10.1101/2021.10.07.21264420; this version posted October 11, 2021. The copyright holder for this preprint (which was not certified by peer review) is the author/funder, who has granted medRxiv a license to display the preprint in It is made available under a CC-BY-NC-ND 4.0 International license .

to the Declaration of Helsinki and the study protocol was approved by the Ethical Committee of the VU University Medical Center. All patients gave their written informed consent in the presence of their caregiver.

\section{Amyloid biomarker assessment}

Between 2016 and 2018, CSF concentrations of $A \beta_{42}$, total tau, and tau phosphorylated at threonine 181 (pTau 181 ) were measured using Innotest ELISAs (Fuijirebio, Ghent, Belgium). Between 2018 and 2020, these CSF biomarkers were assessed using Elecsys $A \beta_{1-42}$ CSF, Elecsys total-tau CSF, and Elecsys pTau ${ }_{181}$ CSF electrochemiluminescence immunoassays (Roche Diagnostics, Basel, Switzerland). For comparability Innotest CSF values were converted using previously published conversion formulas [17]. A pTau/ $A \beta_{42}$-ratio $\geq 0.020$ was considered an $A D$ profile [18].

Amyloid-PET scanning was performed with either ${ }^{18} \mathrm{~F}$-Florbetaben (NeuraCeq), ${ }^{18} \mathrm{~F}$ Florbetapir (Amyvid) or 18F-Flutemetamol (Vizamyl) tracers [19-21]. An experienced nuclear physician (BvB) who completed training for all radiotracers visually assessed images of amyloid-PET scans as positive or negative.

\section{Ophthalmological assessment}

Subjects underwent the following general eye examination: best corrected visual acuity (VA), intraocular pressure (IOP) using non-contact tonometry, and slit-lamp examination of the anterior and posterior segment, followed by administration of tropicamide $0.5 \%$ to dilate the pupil for optimal retinal imaging. An experienced ophthalmologist (FDV) interpreted all examinations. 
medRxiv preprint doi: https://doi.org/10.1101/2021.10.07.21264420; this version posted October $11,2021$. The copyright holder for this
preprint (which was not certified by peer review) is the author/funder, who has granted medRxiv a license to display the preprint in It is made available under a CC-BY-NC-ND 4.0 International license .

\section{Heidelberg HRA SLO imaging}

Retinal fluorescence imaging was performed with a Heidelberg Engineering Spectralis Spectral Domain Scanning Laser Ophthalmoscope, at a 486nm wavelength (blue autofluorescence) laser source to excite fluorescence, in combination with a long-pass 500 filter (high transmission in 498-760nm and 800$835 \mathrm{~nm})$. Optical resolution was $12 \mu \mathrm{m}$ with a $55^{\circ}$ lens, and $6 \mu \mathrm{m}$ with a $30^{\circ}$ lens. For each final image an average of 50 frames was used with a sensitivity $>90$.

\section{Curcumin administration and timing of fluorescence imaging}

Three different oral formulations of curcumin were used:

1. Longvida ${ }^{\circledR}$ Solid-Lipid Curcumin Particle (Verdure Sciences ${ }^{\circledR}$ ), was given in a dosage of $4000 \mathrm{mg}$ per day for 10 consecutive days to 14 AD patients and 12 controls [7]. Here we used a $30^{\circ}$ lens to acquire images in six regions of interest (ROI) (central macula, superior, temporal, inferior, superior-temporal and inferiortemporal) at baseline and after 10 days of curcumin intake (Figure 1A-B).

2. Theracurmin ${ }^{\circledR}$ (Theracurmin; Theravalues, Tokyo, Japan), was given in a dosage of $180 \mathrm{mg}$ for 5 consecutive days to $7 \mathrm{AD}$ patients and 2 controls [22, 23]. Here we acquired images using a $30^{\circ}$ lens in three ROl's (central macula, optic nerve head $(\mathrm{ONH})$ and temporal) at four different time points: i) at baseline, ii) after four days of curcumin intake, iii) 1 hour after the fifth dose, and iv) 2 hour after the fifth dose (Figure $1 \mathrm{~A}-\mathrm{B}$ ).

3. Novaso ${ }^{\circledR}$ (AQUANOVA AG, Darmstadt, Germany), was given in a dosage of 300 $\mathrm{mg}$ for 4 consecutive days and a final dose of $500 \mathrm{mg}$ on day 5 to 5 AD patients [24, 25]. With Novasol we acquired images using a $55^{\circ}$ lens in six ROI's (central macula, 
medRxiv preprint doi: https://doi.org/10.1101/2021.10.07.21264420; this version posted October 11,2021 . The copyright holder for this preprint (which was not certified by peer review) is the author/funder, who has granted medRxiv a license to display the preprint in It is made available under a CC-BY-NC-ND 4.0 International license .

superior, temporal, inferior, superior-temporal and inferior-temporal) at baseline and 2 hours after the fifth dose (Figure 1A-B).

\section{Retinal fluorescence image analysis}

Baseline and post-curcumin-administration images were assessed both visually and quantitatively. Visual assessment was performed by an experienced ophthalmologist blinded for diagnosis (FDV). Baseline and post-curcumin-administration images were compared for $A D$ and control subjects for all three curcumin formulations. To support the visual assessment, Longvida ${ }^{\circledR}$ images of sufficient quality (scans that were out of focus, had extensive shading or extreme low/high contrast were excluded) were assessed for quantitative analysis (Figure 1C). Retinal fluorescence imaging yielded 8-bit grayscale images sized $1536 \times 1566$ pixels with a resolution of $6 \mu \mathrm{m}$ per pixel. The non-normalized, uncompressed images were compared between time points using MATLAB 2020b (MathWorks). An image pair of two time points of similar ROl's were cropped to a size of $1200 \times 1200$ pixels to remove the manufacturer logo and blurry edges. A registration algorithm (feature-based registration (SURF: SpeededUp Robust Features www.sciencedirect.com/science/article/pii/S1077314207001555) with affine transformation, allowing for rotation) was used to register matched images. If no match was obtained, the ROI was dismissed, and the next image pair of a different ROI was matched. Registered images were cropped to a size of $512 \times 512$ pixels, ensuring that both images overlapped within the imaged field of view.

Brightness histograms of both images were obtained and matched (using a cubic polynomial) to the histogram of the baseline image, resulting in images with similar 
medRxiv preprint doi: https://doi.org/10.1101/2021.10.07.21264420; this version posted October 11,2021 . The copyright holder for this preprint (which was not certified by peer review) is the author/funder, who has granted medRxiv a license to display the preprint in It is made available under a CC-BY-NC-ND 4.0 International license .

contrast and overall brightness. We defined focal retinal hyperfluorescence, by selecting areas of $\geq 4$ adjacent pixels that represented the $10 \%$ highest pixel value. Areas with hyperfluorescence were quantitatively assessed at baseline, postcurcumin and the difference between baseline and post-curcumin.

\section{Curcuminoids plasma level analysis}

Blood was drawn in heparinized tubes that were directly kept in aluminum foil on ice, to avoid degradation by light and temperature. Within 30 minutes, plasma and serum were separated and plasma was stored at minus $80^{\circ} \mathrm{C}$ in the Amsterdam UMC Biobank. High Performance Liquid Chromatography-Tandem Mass Spectroscopy (HPLC-MS-MS) analysis was performed to measure different curcuminoids: curcumin, demethoxycurcumin, bisdemethoxycurcumin and tetrahydrocurcumin. Each sample was treated, in duplicates, with and without $\beta$-glucuronidase after which unconjugated and conjugated curcuminoids were quantified. Treatment with $\beta$ glucuronidase hydrolyzes the conjugated curcuminoids leading to an increase in unconjugated curcuminoids, whereas untreated samples were quantified on unconjugated curcumin at that point of time. Our validated method of analysis can be described, in short, as follows: Liquid-liquid extraction with Tert Butyl Methyl Ether (TBME) was used to extract the compounds from the plasma. The HPLC-MS/MS system consisted of an Ultimate 3000 autosampler and pump, both of Dionex, connected to a degasser from LC Packings. The autosampler, with a $100 \mu \mathrm{L}$ sample loop, was coupled to an Sciex API4000 mass spectrometer. A total of $50 \mu \mathrm{L}$ sample was injected after which separation of the analytes was performed with an Agilent column $2.1 \times 100 \mathrm{~mm}$ packed with material of Zorbax Extend $3.5 \mu \mathrm{m} \mathrm{C}-18$. The flowrate was $0.200 \mu \mathrm{L} / \mathrm{min}$ and the dual gradient mobile phase consisted of A: ultra- 
medRxiv preprint doi: https://doi.org/10.1101/2021.10.07.21264420; this version posted October $11,2021$. The copyright holder for this
preprint (which was not certified by peer review) is the author/funder, who has granted medRxiv a license to display the preprint in It is made available under a CC-BY-NC-ND 4.0 International license .

purified $\mathrm{H} 2 \mathrm{O}$ with $0.1 \%$ formic acid and $\mathrm{B}$ : $\mathrm{MeOH} 100 \%$. The applied gradient profile started at 50:50 A:B and increased linear to $95 \%$ B in 3.0 minutes. During 6 minutes a 5:95 A:B level is continued, after which it returned in 0.2 minutes to $50: 50$.

Afterwards the system was equilibrated during 6 minutes at the starting level. Throughout the liquid-liquid extraction and HPLC-MS/MS the potential influence of light brought back to a minimum by working in a dark environment. Each analytical run included a set of freshly prepared calibration samples containing all compounds in the validated range of $2 \mathrm{nM}$ to $400 \mathrm{nM}$. Each compound was validated with its own deuterated internal standard.

\section{Statistical analysis}

SPSS version 26.0 (IBM, Armonk, NY, USA) was used to assess group differences in demographics, curcumin data and quantitative retinal fluorescence. Chi squared test was used for dichotomous variables, independent sample T-test was used for continuous variables that were normally distributed and Mann Whitney U Test was used for non-normal distributed variables. Quantitative comparison of focal retinal hyperfluorescence between AD patients and controls was assessed by calculating the number of focal retinal hyperfluorescence pixels defined as a value in the top $10 \%$ value range at baseline and after curcumin, for all retinal regions of the right eye. Between group differences were assessed using a Mann Whitney $U$ test. Significance level for all tests was set at 0.05 .

\section{Results}

Demographics of $A D$ and control cases are shown in table 1, and supplemental table 1 shows data for each individual participant. The control group comprised more 
medRxiv preprint doi: https://doi.org/10.1101/2021.10.07.21264420; this version posted October $11,2021$. The copyright holder for this
preprint (which was not certified by peer review) is the author/funder, who has granted medRxiv a license to display the preprint in It is made available under a CC-BY-NC-ND 4.0 International license .

female participants. No differences were found for age between $A D$ and control group. As expected (by design), we found significant group differences for MMSE as well as CSF and amyloid-PET biomarkers.

\section{Qualitative and quantitative retinal fluorescence analysis}

The qualitative assessment of images pre- and post-curcumin intake by an experienced ophthalmologist (FDV) blinded for the clinical diagnosis did not show differences in focal hyperfluorescence in the ROl's imaged, for either AD patients or controls for all the three curcumin formulations (Figure 2 and supplemental Figures 1 and 2).

Scans with 30-degree lens of 7 AD patients and 7 controls who used Longvida ${ }^{\circledR}$ allowed for quantitative analysis. No differences were found in number of focal retinal hyperfluorescence between AD patients and controls at baseline for all ROls, nor did we find a group differences in increase of retinal hyperfluorescence after curcumin intake (all p-values>0.3) (Supplemental table 2).

\section{Curcumin plasma level analysis}

HPLC-MS/MS analysis of plasma samples showed no detectable levels of free curcumin in blood after Longvida ${ }^{\circledR}$, Theracurmin ${ }^{\circledR}$ or Novaso ${ }^{\circledR}$ intake in all 40 subjects. After treating the samples with $\beta$-glucuronidase, catalyzing the separation of curcumin from glucuronide and sulfate conjugates, curcumin levels were detectable (Table 2). The total mean of curcuminoids was $156.2 \mathrm{nM}( \pm 169.9)$ after Longvida $^{\circledR}, 576.6 \mathrm{nM}( \pm 211.1)$ after Theracurmin ${ }^{\circledR}$ and $1605.8 \mathrm{nM}( \pm 524.6 \mathrm{nM})$ after Novaso $^{\circledR}($ Figure 3). 
medRxiv preprint doi: https://doi.org/10.1101/2021.10.07.21264420; this version posted October 11, 2021. The copyright holder for this

\section{Discussion}

The retina is increasingly recognized as a promising target to identify early $A D$ changes $[5,6]$. Curcumin is a polipotent polyphenol with fluorescent properties known to bind to amyloid [26, 27]. In this study we aimed to discriminate AD patients from controls with a targeted fluorescence approach of the retina using curcumin as fluorophore in a well-characterized AD biomarker confirmed cohort. Using three different curcumin formulations, we did not find differences in focal retinal hyperfluorescence before or after curcumin intake.

Our negative findings may be explained by a low intensity of the fluorescent signal supposedly related to retinal amyloid. Fluorescence of curcumin largely overlaps with autofluorescence of the retina mainly caused by $\mathrm{N}$-retinylidene-N-retinylethanolamine (A2E) and lipofuscin. Retinal autofluorescence might therefore mask subtle signals of curcumin fluorescence resulting from supposed amyloid pathology, approximately 5$20 \mu \mathrm{m}$ in size. At present no data is available describing the magnitude of fluorescent signal that can be expected from retinal amyloid relative to retinal autofluorescence. On visual inspection we could identify a certain number of hyperfluorescent spots, however there was no difference between AD patients and controls, neither at baseline, nor after curcumin intake. To increase sensitivity for weak retinal 

medRxiv preprint doi: https://doi.org/10.1101/2021.10.07.21264420; this version posted October $11,2021$. The copyright holder for this
preprint (which was not certified by peer review) is the author/funder, who has granted medRxiv a license to display the preprint in It is made available under a CC-BY-NC-ND 4.0 International license .

fluorescent signal possibly overlooked by visual inspection, we performed a quantitative approach confirming findings of the visual inspection.

The absence of a fluorescent signal after curcumin intake could also be explained by curcumin insufficiently binding to retinal amyloid due to low plasma levels. In the past years several formulations were developed claiming higher bioavailability, which led us to not only use Longvida ${ }^{\circledR}$, but also Theracurmin ${ }^{\circledast}$ and Novaso ${ }^{\circledR}$. For all three formulations we could not detect levels of unconjugated curcumin in blood. After deconjugation using $\beta$-glucuronidase treatment we observed higher blood levels of total curcumin with Novaso ${ }^{\circledR}$ and Theracurmin ${ }^{\circledR}$ compared to Longvida ${ }^{\circledR}$, which is in line with previous studies using these formulations [22, 24]. In contrast, Koronyo et al. found fairly high levels of unconjugated curcumin (400nM) without describing the use of $\beta$-glucuronidase [7]. These higher concentrations could be attributed by their divergent method of analyses in a small subset of patients $(n=6)$. First, these authors applied wider/broader settings of calibration to enhance their signal. Second, internal standards did not consist of deuterated forms and were validated in mouse (instead of human) plasma samples. And third, obtained blood samples were acidified to prevent curcumin reduction and degradation, which is not representative for the invivo situation where blood has neutral $\mathrm{pH}$ and curcumin further degrades rapidly.

Conjugated forms of curcumin are known to bind to amyloid as well [26]. This implies that an absence of free curcumin in the plasma, as observed in our study, cannot explain our negative findings. Despite 3-4 times higher plasma levels of total curcumin using Theracurmin ${ }^{\circledR}$ and Novaso ${ }^{\circledR}{ }^{\text {compared to Longvida }}{ }^{\circledR}$, we found no difference in focal retinal hyperfluorescence between AD patients and controls. 
medRxiv preprint doi: https://doi.org/10.1101/2021.10.07.21264420; this version posted October 11,2021 . The copyright holder for this preprint (which was not certified by peer review) is the author/funder, who has granted medRxiv a license to display the preprint in It is made available under a CC-BY-NC-ND 4.0 International license .

Moreover, previous work describes that hyperfluorescent spots (attributed to amyloid by these authors) are visible in the retina even without application of curcumin [7]. We found, however, no difference in focal retinal hyperfluorescence between $A D$ patients and controls before curcumin administration.

The lack of between-group differences in our study could also be explained by absence of amyloid in the retina. The presence of amyloid in the human retina is not unequivocally proven, as one lab showed presence of retinal amyloid plaques in post-mortem retinas, while others were unable to replicate these findings $[7,10,12$ 14, 28]. Methodological heterogeneity in post-mortem study methods might account for these discrepancies. First, retinas were processed as cross sections, flat mounts or punches and second different amyloid antibodies were used. Replication studies and harmonization in study methods are needed to overcome these discrepancies before the presence of retinal amyloid in AD can undoubtedly be confirmed. In-vivo, three studies showed hyperfluorescence in AD cases after curcumin intake [7-9]. However, these studies were either small or lacked biomarker confirmation. Next to methodological differences also a difference in interpretation of observed hyperfluorescent areas may account for discrepancies. Several retinal changes may underlie changes in fluorescence. For example, retinal drusen, associated with macular degeneration, contain a great variety of constituents, including amyloid and lipofuscin, and other age-related deposits, that may give similar changes in fluorescence $[29,30]$. Thus, the observed hyperfluorescent signal in previous studies could also be explained by age related retinal changes, such as drusen [7-9, 30]. Remarkably, in the study of Koronyo et al. AD patients had a mean age of 76 years compared to 53 years in controls, which possibly supports this hypothesis [7]. More 

medRxiv preprint doi: https://doi.org/10.1101/2021.10.07.21264420; this version posted October $11,2021$. The copyright holder for this
preprint (which was not certified by peer review) is the author/funder, who has granted medRxiv a license to display the preprint in It is made available under a CC-BY-NC-ND 4.0 International license .

work is needed to discriminate normal aging from pathological neurodegenerative changes in the retina underlying changes in retinal fluorescence.

There are some limitations in this study. First, little is known about the temporal properties of curcumin binding to retinal amyloid and its relation to systemically available curcumin and conjugates following oral intake. The optimal time point to measure retinal fluorescence is still to be determined. We based our scan timing on previously published pharmacokinetic curves of systemically available curcumin representing assumed peak levels of systemic curcumin, as has been shown to yield signal before[7, 22-25]. Nevertheless our scan timing might have been suboptimal for measuring curcumin bound to retinal amyloid resulting in impaired sensitivity. Second, given the sensitivity of quantitative analysis for small alterations in scan quality affecting the co-registration of baseline and follow up scans, we could only include $7 \mathrm{AD}$ and 7 control subjects. Inclusion of more subjects could have increased the power of our quantitative analysis. However, since there was no statistical trend of difference between groups, it is highly doubtful that this would have changed our results.

In conclusion, we found no focal retinal hyperfluorescence in AD patients or controls pre- and post-curcumin, even when using curcumin formulations that yielded higher plasma levels than Longvida ${ }^{\circledR}$, a formulation previously used for this purpose. We question whether retinal hyperfluorescence described in previous work, represents retinal amyloid, or rather age-related changes, as we could not replicate these findings with similar methods in an amyloid biomarker confirmed cohort. As such, retinal hyperfluoresence is currently not ready for use as AD biomarker. 
medRxiv preprint doi: https://doi.org/10.1101/2021.10.07.21264420; this version posted October 11, 2021. The copyright holder for this preprint (which was not certified by peer review) is the author/funder, who has granted medRxiv a license to display the preprint in It is made available under a CC-BY-NC-ND 4.0 International license . 
medRxiv preprint doi: https://doi.org/10.1101/2021.10.07.21264420; this version posted October 11, 2021. The copyright holder for this preprint (which was not certified by peer review) is the author/funder, who has granted medRxiv a license to display the preprint in It is made available under a CC-BY-NC-ND 4.0 International license .

\section{References}

1. Jack, C.R., Jr., et al., NIA-AA Research Framework: Toward a biological definition of Alzheimer's disease. Alzheimers Dement, 2018. 14(4): p. 535562.

2. Sperling, R.A., et al., Toward defining the preclinical stages of Alzheimer's disease: recommendations from the National Institute on Aging-Alzheimer's Association workgroups on diagnostic guidelines for Alzheimer's disease. Alzheimers Dement, 2011. 7(3): p. 280-92.

3. Scheltens, P., et al., Alzheimer's disease. Lancet, 2021. 397(10284): p. 15771590.

4. Alber, J., et al., Developing retinal biomarkers for the earliest stages of Alzheimer's disease: What we know, what we don't, and how to move forward. Alzheimers Dement, 2020. 16(1): p. 229-243.

5. Gupta, V.B., et al., Retinal changes in Alzheimer's disease- integrated prospects of imaging, functional and molecular advances. Prog Retin Eye Res, 2020: p. 100899.

6. Snyder, P.J., et al., Retinal imaging in Alzheimer's and neurodegenerative diseases. Alzheimers Dement, 2021. 17(1): p. 103-111.

7. Koronyo, Y., et al., Retinal amyloid pathology and proof-of-concept imaging trial in Alzheimer's disease. JCl Insight, 2017. 2(16).

8. Tadokoro, K., et al., Retinal Amyloid Imaging for Screening Alzheimer's Disease. J Alzheimers Dis, 2021.

9. Ngolab, J., et al., Feasibility study for detection of retinal amyloid in clinical trials: The Anti-Amyloid Treatment in Asymptomatic Alzheimer's Disease (A4) trial. Alzheimers Dement (Amst), 2021. 13(1): p. e12199.

10. den Haan, J., et al., Amyloid-beta and phosphorylated tau in post-mortem Alzheimer's disease retinas. Acta Neuropathol Commun, 2018. 6(1): p. 147.

11. Jiang, J., et al., Amyloid Plaques in Retina for Diagnosis in Alzheimer's Patients: a Meta-Analysis. Front Aging Neurosci, 2016. 8: p. 267.

12. Williams, E.A., et al., Absence of Alzheimer Disease Neuropathologic Changes in Eyes of Subjects With Alzheimer Disease. J Neuropathol Exp Neurol, 2017. 76(5): p. 376-383.

13. Ho, C.Y., et al., Beta-amyloid, phospho-tau and alpha-synuclein deposits similar to those in the brain are not identified in the eyes of Alzheimer's and Parkinson's disease patients. Brain Pathol, 2014. 24(1): p. 25-32.

14. Schön, C., et al., Long-Term In Vivo Imaging of Fibrillar Tau in the Retina of P301S Transgenic Mice. PLoS ONE, 2012. 7(12): p. 1-9.

15. Konijnenberg, E., et al., The EMIF-AD PreclinAD study: study design and baseline cohort overview. Alzheimers Res Ther, 2018. 10(1): p. 75.

16. van der Flier, W.M. and P. Scheltens, Amsterdam Dementia Cohort: Performing Research to Optimize Care. J Alzheimers Dis, 2018. 62(3): p. 1091-1111.

17. Willemse, E.A.J., et al., Diagnostic performance of Elecsys immunoassays for cerebrospinal fluid Alzheimer's disease biomarkers in a nonacademic, multicenter memory clinic cohort: The ABIDE project. Alzheimers Dement (Amst), 2018. 10: p. 563-572.

18. Willemse, E.A.J., et al., Comparing CSF amyloid-beta biomarker ratios for two automated immunoassays, Elecsys and Lumipulse, with amyloid PET status. Alzheimers Dement (Amst), 2021. 13(1): p. e12182. 
medRxiv preprint doi: https://doi.org/10.1101/2021.10.07.21264420; this version posted October 11, 2021. The copyright holder for this preprint (which was not certified by peer review) is the author/funder, who has granted medRxiv a license to display the preprint in It is made available under a CC-BY-NC-ND 4.0 International license .

19. Barthel, H., et al., Cerebral amyloid- $\beta$ PET with florbetaben (18F) in patients with Alzheimer's disease and healthy controls: a multicentre phase 2 diagnostic study. Lancet Neurol, 2011. 10(5): p. 424-35.

20. Clark, C.M., et al., Use of florbetapir-PET for imaging beta-amyloid pathology. Jama, 2011. 305(3): p. 275-83.

21. Curtis, C., et al., Phase 3 trial of flutemetamol labeled with radioactive fluorine 18 imaging and neuritic plaque density. JAMA Neurol, 2015. 72(3): p. 287-94.

22. Kanai, M., et al., $A$ phase $i$ study investigating the safety and pharmacokinetics of highly bioavailable curcumin (Theracurmin $\Theta$ ) in cancer patients. Cancer Chemotherapy and Pharmacology, 2013. 71(6): p. 1521-1530.

23. Sasaki, H., et al., Innovative preparation of curcumin for improved oral bioavailability. Biological \& pharmaceutical bulletin, 2011. 34(5): p. 660-665.

24. Schiborr, C., et al., The oral bioavailability of curcumin from micronized powder and liquid micelles is significantly increased in healthy humans and differs between sexes. Mol Nutr Food Res, 2014. 58(3): p. 516-27.

25. Kocher, A., et al., Highly bioavailable micellar curcuminoids accumulate in blood, are safe and do not reduce blood lipids and inflammation markers in moderately hyperlipidaemic individuals. Mol Nutr Food Res, 2016.

26. den Haan, J., et al., Different curcumin forms selectively bind fibrillar amyloid beta in post mortem Alzheimer's disease brains: Implications for in-vivo diagnostics. Acta Neuropathol Commun, 2018. 6(1): p. 75.

27. Heger, M., et al., The molecular basis for the pharmacokinetics and pharmacodynamics of curcumin and its metabolites in relation to cancer. Pharmacol Rev, 2014. 66(1): p. 222-307.

28. Koronyo-Hamaoui, M., et al., Identification of amyloid plaques in retinas from Alzheimer's patients and noninvasive in vivo optical imaging of retinal plaques in a mouse model. Neurolmage, 2011. 54(SUPPL. 1): p. S204-S217.

29. Luibl, V., et al., Drusen deposits associated with aging and age-related macular degeneration contain nonfibrillar amyloid oligomers. J Clin Invest, 2006. 116(2): p. 378-85.

30. Bergen, A.A., et al., On the origin of proteins in human drusen: The meet, greet and stick hypothesis. Prog Retin Eye Res, 2018. 
medRxiv preprint doi: https://doi.org/10.1101/2021.10.07.21264420; this version posted October 11, 2021. The copyright holder for this preprint (which was not certified by peer review) is the author/funder, who has granted medRxiv a license to display the preprint in It is made available under a CC-BY-NC-ND 4.0 International license .

\section{Authors' contributions}

\begin{tabular}{|c|c|}
\hline Author & Contributions \\
\hline Jurre den Haan & $\begin{array}{l}\text { Literature search, study design, data collection, data } \\
\text { analysis, data interpretation, figures, writing-original draft. } \\
\text { Verified data. }\end{array}$ \\
\hline $\begin{array}{l}\text { Frederique Hart de } \\
\text { Ruyter }\end{array}$ & $\begin{array}{l}\text { Data collection, data analysis, data interpretation, writing- } \\
\text { review and editing }\end{array}$ \\
\hline Benjamin Lochocki & $\begin{array}{l}\text { Image analysis, quantitative data analysis, data } \\
\text { interpretation, writing-review and editing }\end{array}$ \\
\hline $\begin{array}{l}\text { Maurice A.G.M. } \\
\text { Kroon }\end{array}$ & $\begin{array}{l}\text { Data collection plasma analysis, data analysis, data } \\
\text { interpretation, writing-original draft }\end{array}$ \\
\hline Marleen E. Kemper & $\begin{array}{l}\text { Methodology plasma analysis, writing-review and editing, } \\
\text { supervision }\end{array}$ \\
\hline $\begin{array}{l}\text { Charlotte E. } \\
\text { Teunissen }\end{array}$ & Biomarker data interpretation, writing-review and editing \\
\hline Bart van Berckel & Biomarker data interpretation, writing-review and editing \\
\hline Philip Scheltens & Funding acquisition, writing-review and editing \\
\hline $\begin{array}{l}\text { Jeroen J. } \\
\text { Hoozemans }\end{array}$ & Data interpretation, writing-review and editing \\
\hline Aleid Kreeke & Data collection \\
\hline Frank D. Verbraak & $\begin{array}{l}\text { Methodology, study design, image data collection, data } \\
\text { analysis, data interpretation, writing-review\&editing. } \\
\text { Verified data. }\end{array}$ \\
\hline Johannes F. de Boer & $\begin{array}{l}\text { Funding acquisition, methodology, study design, data } \\
\text { interpretation, writing-review and editing. Verified data. }\end{array}$ \\
\hline Femke H. Bouwman & $\begin{array}{l}\text { Funding acquisition, study design, data analysis, data } \\
\text { interpretation, writing-original draft. Verified data. }\end{array}$ \\
\hline
\end{tabular}


medRxiv preprint doi: https://doi.org/10.1101/2021.10.07.21264420; this version posted October 11,2021 . The copyright holder for this preprint (which was not certified by peer review) is the author/funder, who has granted medRxiv a license to display the preprint in It is made available under a CC-BY-NC-ND 4.0 International license .

\section{Conflicts of interest}

Research of CT is supported by the European Commission (Marie Curie International Training Network, grant agreement No 860197 (MIRIADE), and JPND), Health Holland, the Dutch Research Council (ZonMW), Alzheimer Drug Discovery Foundation, The Selfridges Group Foundation, Alzheimer Netherlands, Alzheimer Association. CT is recipients of $A B O A R D$, which is a public-private partnership receiving funding from ZonMW (\#73305095007) and Health Holland, Topsector Life Sciences \& Health (PPP-allowance; \#LSHM20106). More than 30 partners participate in ABOARD. ABOARD also receives funding from Edwin Bouw Fonds and Gieskes-Strijbisfonds. CT has a collaboration contract with ADx Neurosciences, Quanterix and Eli Lilly, performed contract research or received grants from ACImmune, Axon Neurosciences, Biogen, Brainstorm Therapeutics, Celgene, EIP Pharma, Eisai, PeopleBio, Roche, Toyama, Vivoryon. FB has a collaboration contract with Biogen, Optina Dx and Roche. Payments are made to the institution of VUMC. FB is committee member of EAN and chairs the atypical AD PIA and the Eye as biomarker for AD PIA of ISTAART. PS is chair steering committee in NOVARTIS, member DSMB GENENTECH, global PI phase s! study AC IMMUNE, member advisory board AXON NEUROSCIENCE, global PI phase 2B study EIP PHARMA, PI phase 2B study COGRX, member advisory board GEMVAX, COGNOPTIX and CORTEXZYME, member strategic innovation committee GREEN VALLEY, PI global phase 2B study Vivoryon, PI global phase 2A study TOYAMA / FUJI FILM, PI global phase 1A study IONIS, personal fees from Life Science Partners Amsterdam, outside the submitted work. JB is supported for the current study by NWO (Foundation for scientific research in the Netherlands, similar to NIH and NSF) and Co-financing by Heidelberg engineering as part of the competitive research proposal, 
medRxiv preprint doi: https://doi.org/10.1101/2021.10.07.21264420; this version posted October 11, 2021. The copyright holder for this

preprint (which was not certified by peer review) is the author/funder, who has granted medRxiv a license to display the preprint in It is made available under a CC-BY-NC-ND 4.0 International license.

administered by the funding agency. Both these fundings are paid to institution.

Besides this study JB received past 36 months research grants from Heidelberg, TKI,

TNO, LSHM paid to institution. Personal fees from royalties through former employer,

Massachussets general Hospital, for IP that has been licensed to Terumo,

Heidelberg engineering and Spectrawave as well as fees for expert witness for a UK

based law firm. He is program committee member for a number of conferences,

unpaid. JdH, FH, MK, MK, BB, JH, AK, FV report no conflict of interest

\section{Acknowledgements/Funding}

We gratefully acknowledge financial support from Stichting Alzheimercentrum VUMC, Alzheimer Nederland, the Dutch Technology Foundation STW (grant number 13935), part of the Netherlands Organization for Scientific Research (NWO), and which is partly funded by the Ministry of Economic Affairs, ISAO (grant number 14518).

\section{Data availability}

Raw imaging and clinical data is available upon request

\section{Key Words}

Biomarker, retina, curcumin, amyloid, Alzheimer's disease 


\section{Tables}

\section{Table 1. Demographics}

\begin{tabular}{cccc} 
& $\begin{array}{c}\text { Alzheimer's } \\
\text { disease } \\
n=26\end{array}$ & $\begin{array}{c}\text { Controls } \\
n=14\end{array}$ & p-value \\
\hline \hline Sex (F/M) & $10 / 16$ & $10 / 4$ & $.047^{\mathrm{a}}$ \\
\hline Age, mean (SD) & $67(9)$ & $71(12)$ & $.177^{\mathrm{b}}$ \\
\hline MMSE, median (IQR) & $24(21-26)$ & $29(29-30)$ & $.000^{\mathrm{c}}$ \\
\hline A, median (IQR) & $541(466-744)$ & $1328(982-1551)$ & $.002^{\mathrm{c}}$ \\
\hline Tau, median (IQR) & $320(242-472)$ & $208(123-322)$ & $.060^{\mathrm{c}}$ \\
\hline $\begin{array}{c}\text { pTau, median (IQR) } \\
\text { CSF biomarker profile } \\
\text { (positive/negative) }\end{array}$ & $34(23-44)$ & $19(9-30)$ & $.035^{\mathrm{c}}$ \\
\hline $\begin{array}{c}\text { Amyloid-PET } \\
\text { (positive/negative) }\end{array}$ & $20 / 0$ & $3^{*} / 2$ & $.033^{\mathrm{a}}$ \\
\hline & $17 / 0$ & $0 / 13$ & $.000^{\mathrm{a}}$ \\
\hline
\end{tabular}

CSF data (presented as $\mathrm{pg} / \mathrm{ml}$ ) was available in 20 AD cases and 5 controls.

Amyloid-PET data was available in 17 AD cases and 13 controls. ${ }^{a}$ Chi squared test, bIndependent sample T-test, 'Mann Whitney-U test. *3 controls had a borderline positive biomarker profile, with a negative amyloid-PET. Abbreviations: SD = standard deviation; MMSE = mini mental state exam; IQR = interquartile range; $p$ Tau $=$ phosphorylated tau; CSF $=$ cerebral spinal fluid . 
Table 2. Curcuminoids plasma levels

\begin{tabular}{lccc}
\hline & Longvida $^{\circledR}$ & Theracurmin $^{\circledR}$ & Novasol $^{\circledR}$ \\
\hline Curcumin & $75.1(70.2)$ & $321.80(146.1)$ & $1108.40(503.3)$ \\
\hline Demethoxycurcumin & $55(62.5)$ & $19.49(9.7)$ & $58.72(28.6)$ \\
\hline Bisdemethoxycurcumin & $13.7(12.1)$ & $0.66(0.3)$ & $3.23(2.4)$ \\
\hline Tetrahydrocurcumin & $43.6(44.9)$ & $234.70(95.5)$ & $435.4(73.8)$ \\
\hline Total curcuminoids & $156.2(169.6)$ & $576.6(211.1)$ & $1605.8(524.6)$ \\
\hline
\end{tabular}

Plasma levels (mean $\pm S D$ ) of different curcuminoids (curcumin, demethoxycurcumin, bisdemethoxycurcumin and tetrahydrocurcumin) and total curcuminoids after $\beta$ glucuronidase treatment in nanomolar (nM). Time points for serum level measurement after the start of curcumin intake were 10 days for Longvida ${ }^{\circledR}$ and 5 days for Theracurmin ${ }^{\circledR}$ and Novaso ${ }^{\circledR}$. 
medRxiv preprint doi: https://doi.org/10.1101/2021.10.07.21264420; this version posted October 11, 2021. The copyright holder for this preprint (which was not certified by peer review) is the author/funder, who has granted medRxiv a license to display the preprint in It is made available under a CC-BY-NC-ND 4.0 International license .

\section{Figures}

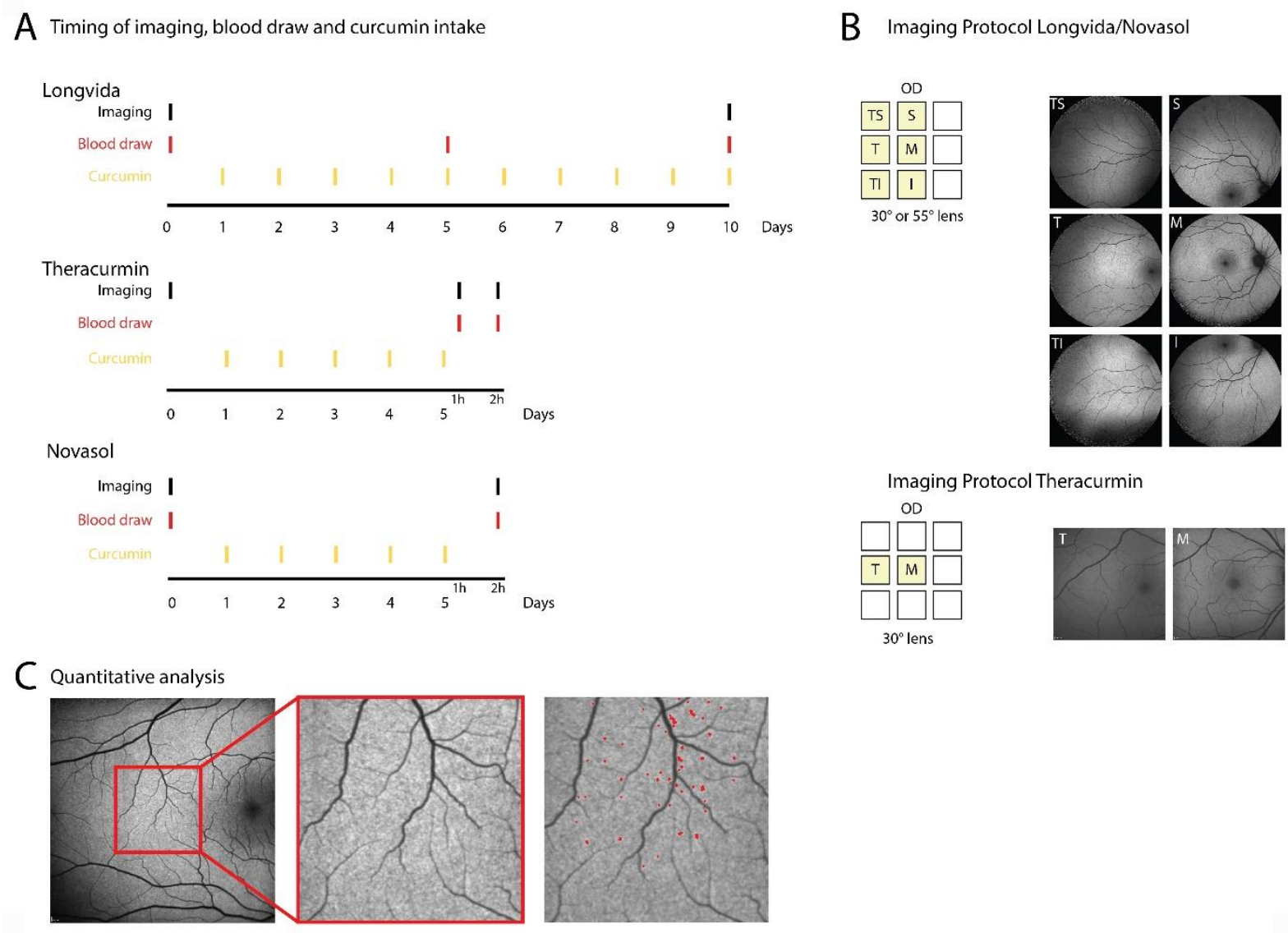

\section{Figure 1. Visual representation of study protocol}

A. Timing of imaging, blood draw and curcumin intake of cohort 1 (Longvida ${ }^{\circledR}, 4000$ $\mathrm{mg}$ for 10 days), cohort 2 (Theracurmin ${ }^{\circledR}, 180 \mathrm{mg}$ for 5 days) and cohort 3 (Novasol ${ }^{\circledR}$, $300 \mathrm{mg}$ for 4 days, $500 \mathrm{mg}$ for 1 day). B. Imaging protocol of cohort 1, 2 and 3. C. Quantitative analysis. 


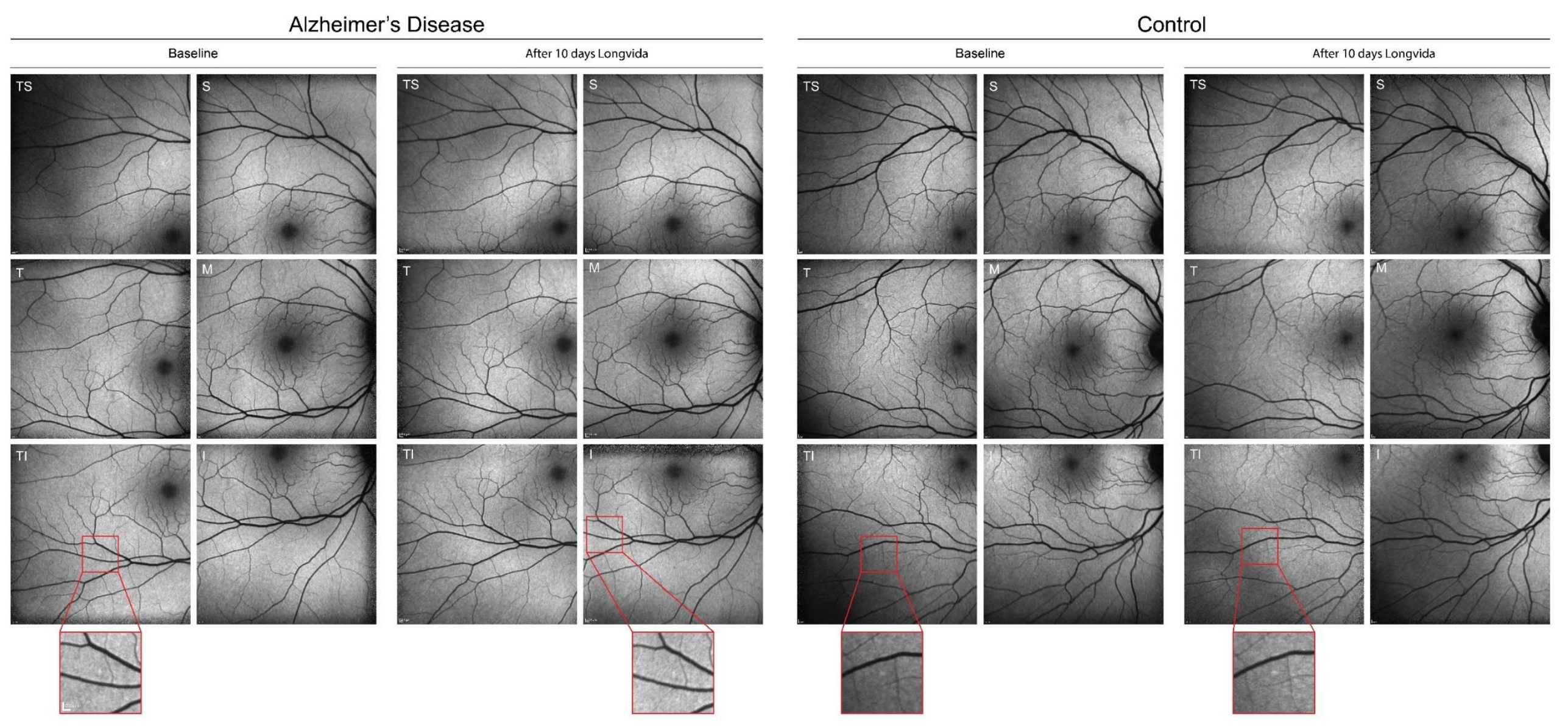

2 Figure 2. Pre- and post-curcumin retinal fluorescence images for $A D$ and control participants using Longvida ${ }^{\circledR}$

3 Pre-and post-curcumin retinal fluorescence images using blue auto fluorescence $(\lambda=486 \mathrm{~nm})$ in 6 retinal regions in a representative 4 AD patient and control. Magnifications show incidental focal hyperfluorescence, both on baseline and after curcumin in AD and

5 control participants. Abbreviations: $\mathrm{TS}=$ temporal-superior, $\mathrm{S}=$ superior, $\mathrm{T}=$ temporal, $\mathrm{M}=$ macula, $\mathrm{T} \mathrm{I}=$ temporal-inferior, $\mathrm{I}=$ inferior. 


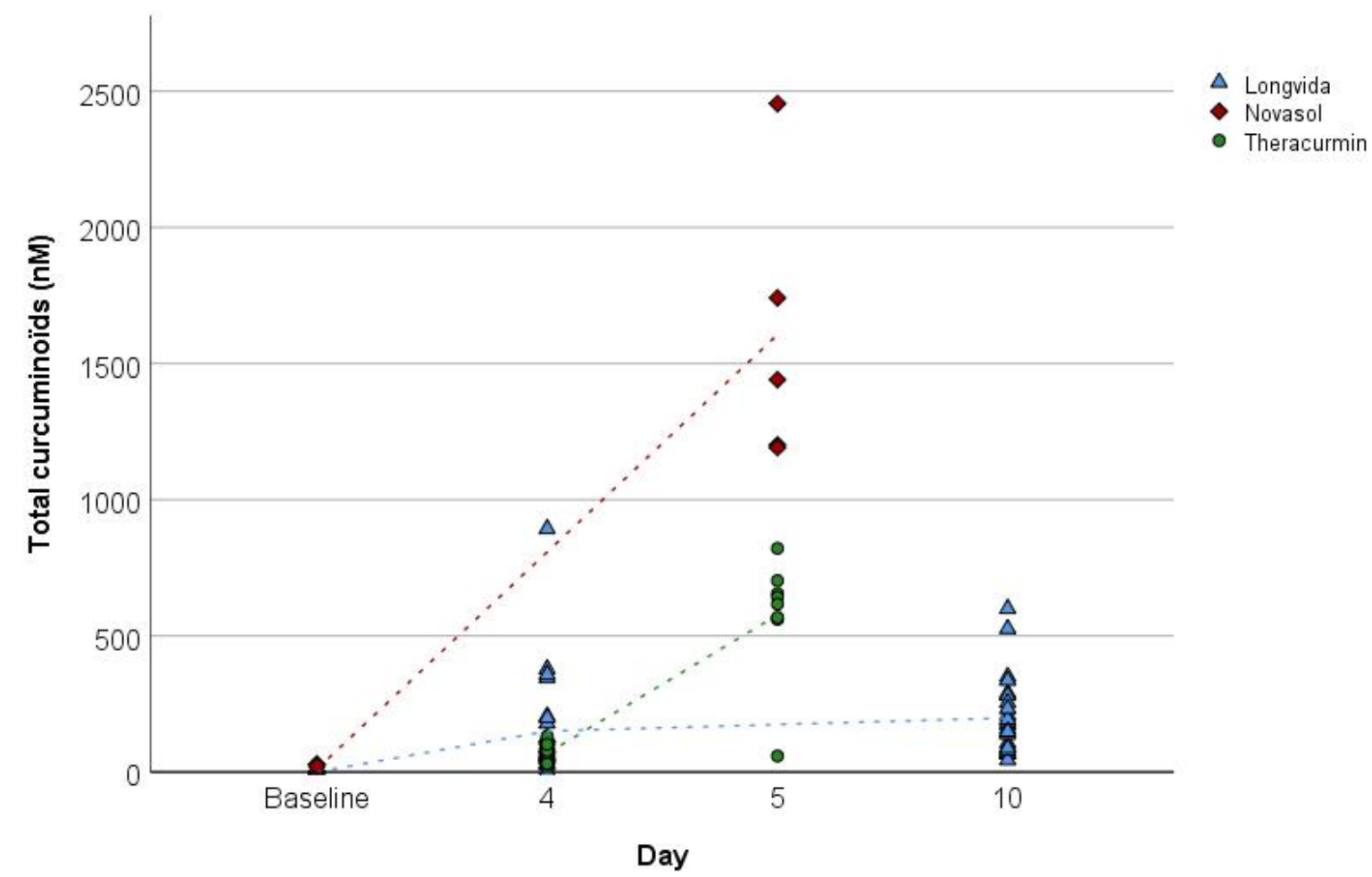

7 Figure 3. Plasma levels of total curcuminoids after Longvida ${ }^{\circledR}$, Theracurmin ${ }^{\circledR}$ and Novasol ${ }^{\circledR}$ intake measured with HPLC-MS/MS

9 Overview of plasma levels of total curcuminoids after Longvida $^{\circledR}$, Theracurmin ${ }^{\circledR}$ and

10 Novaso $^{\circledR}$ intake. Curcumin, demethoxycurcumin, bisdemethoxycurcumin and

11 tetrahydrocurcumin as measured with HPLC-MS/MS after $\beta$-glucuronidase treatment,

12 summed as total curcuminoids in nanomolar (nM). 
preprint (which was not certified by peer review) is the authorffrnder, who has granted medRxiv a license to display the preprint in

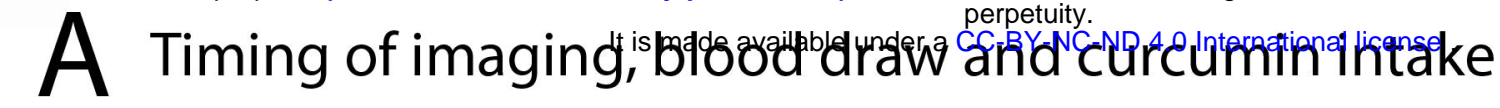

Longvida

Imaging I

0

$\begin{array}{lll}1 & 2 & 3\end{array}$

5

B Imaging Protocol Longvida/Novasol

\section{Theracurmin}

Imaging |

Blood draw

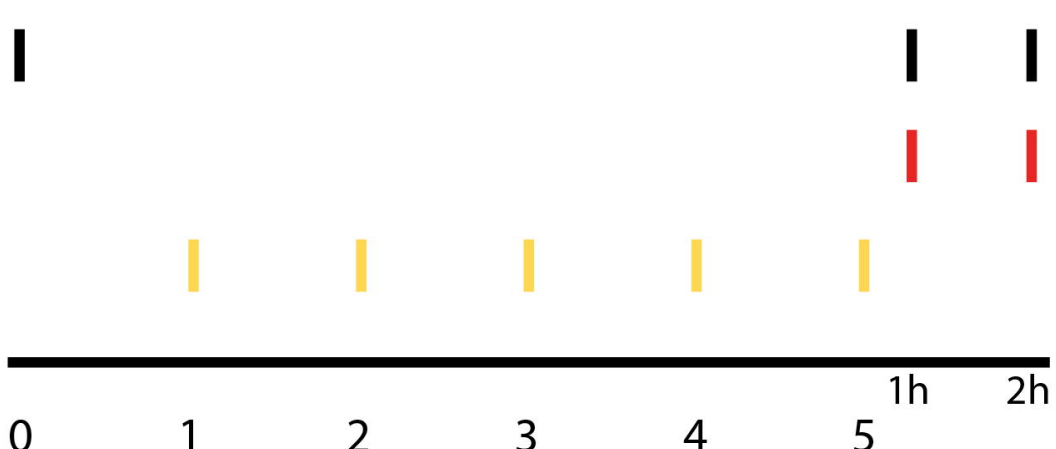

Novasol

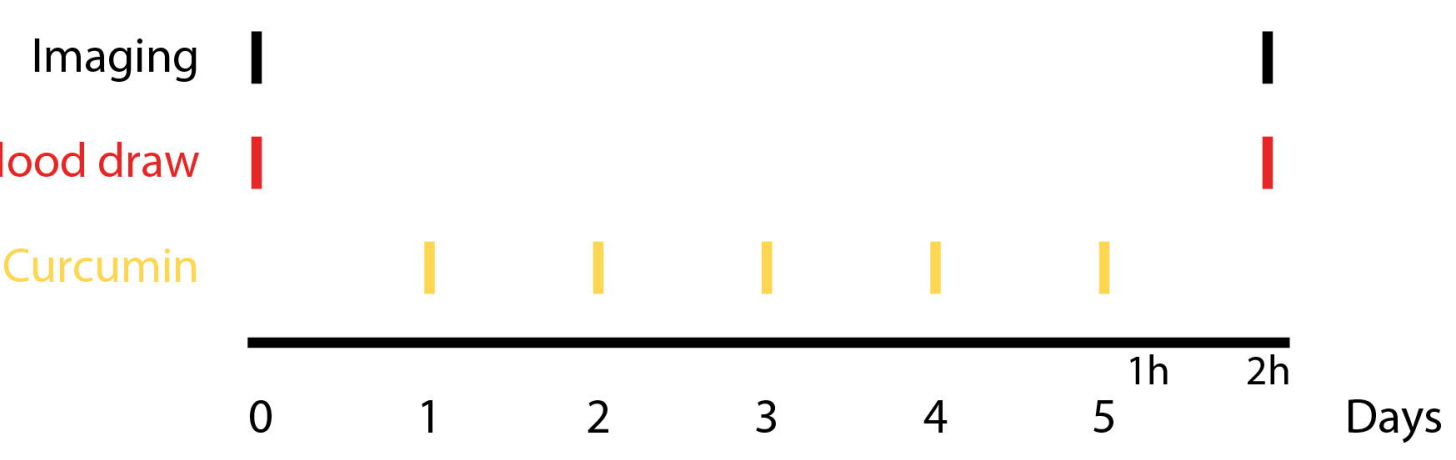

C Quantitative analysis

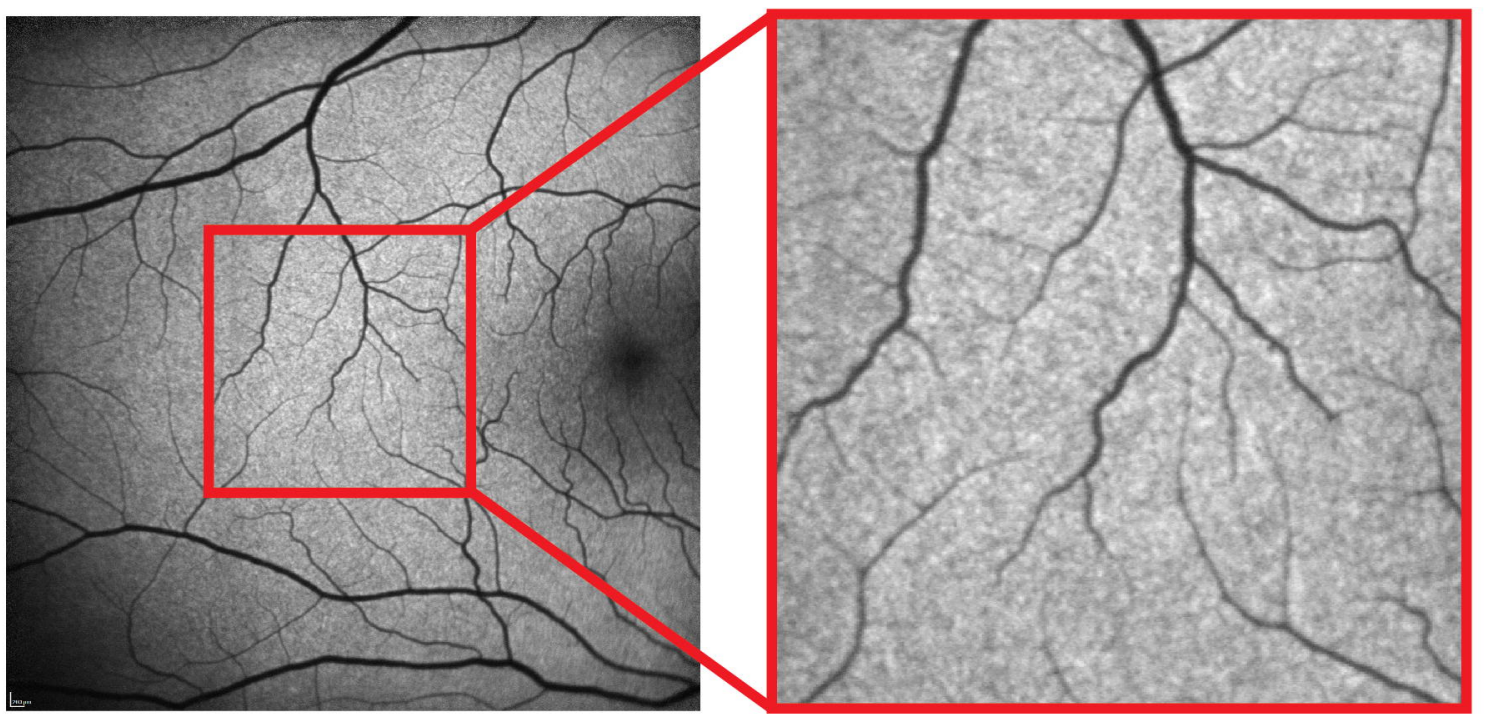

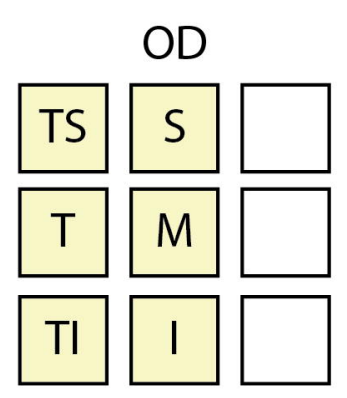

$30^{\circ}$ or $55^{\circ}$ lens

10 Days
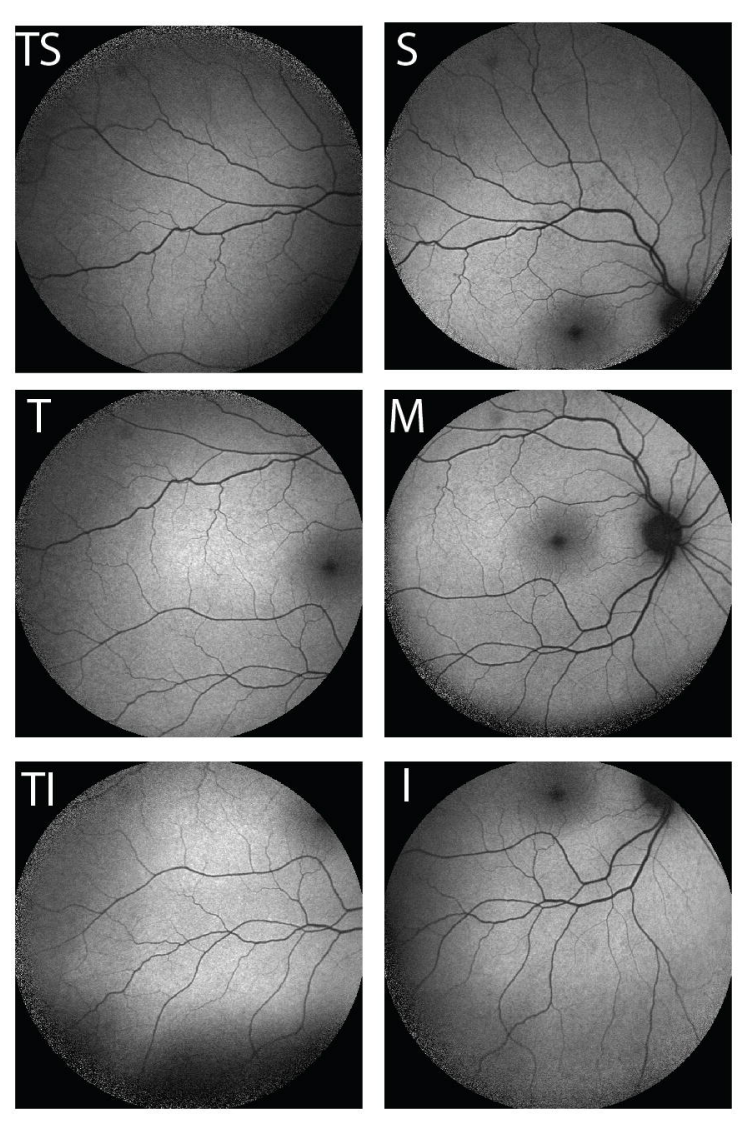

Imaging Protocol Theracurmin

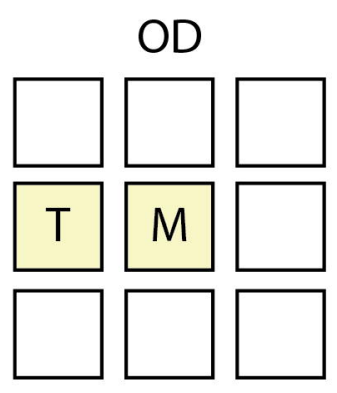

$30^{\circ}$ lens
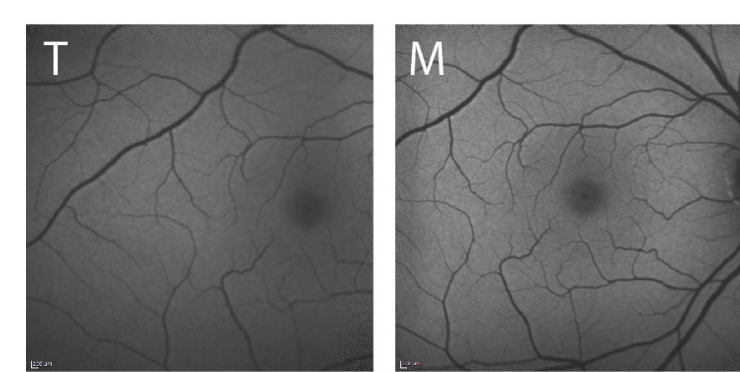

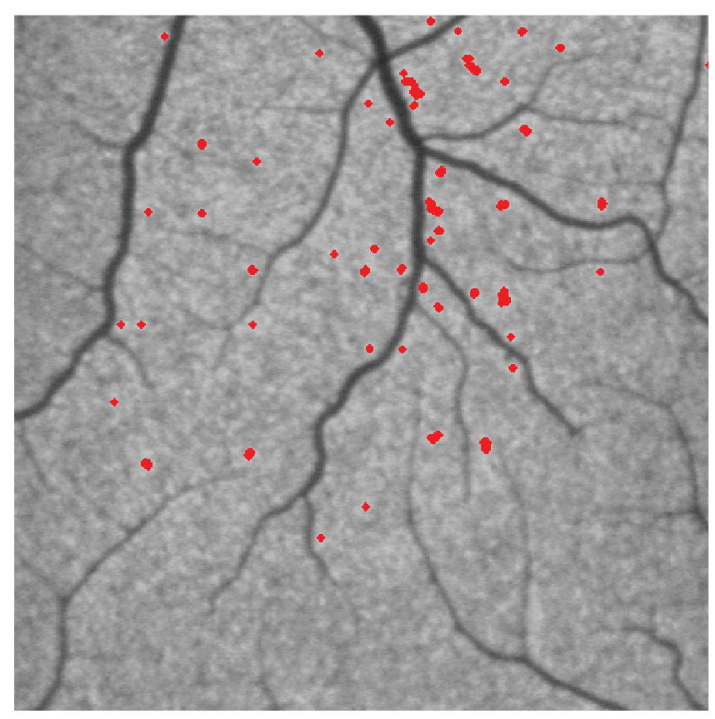









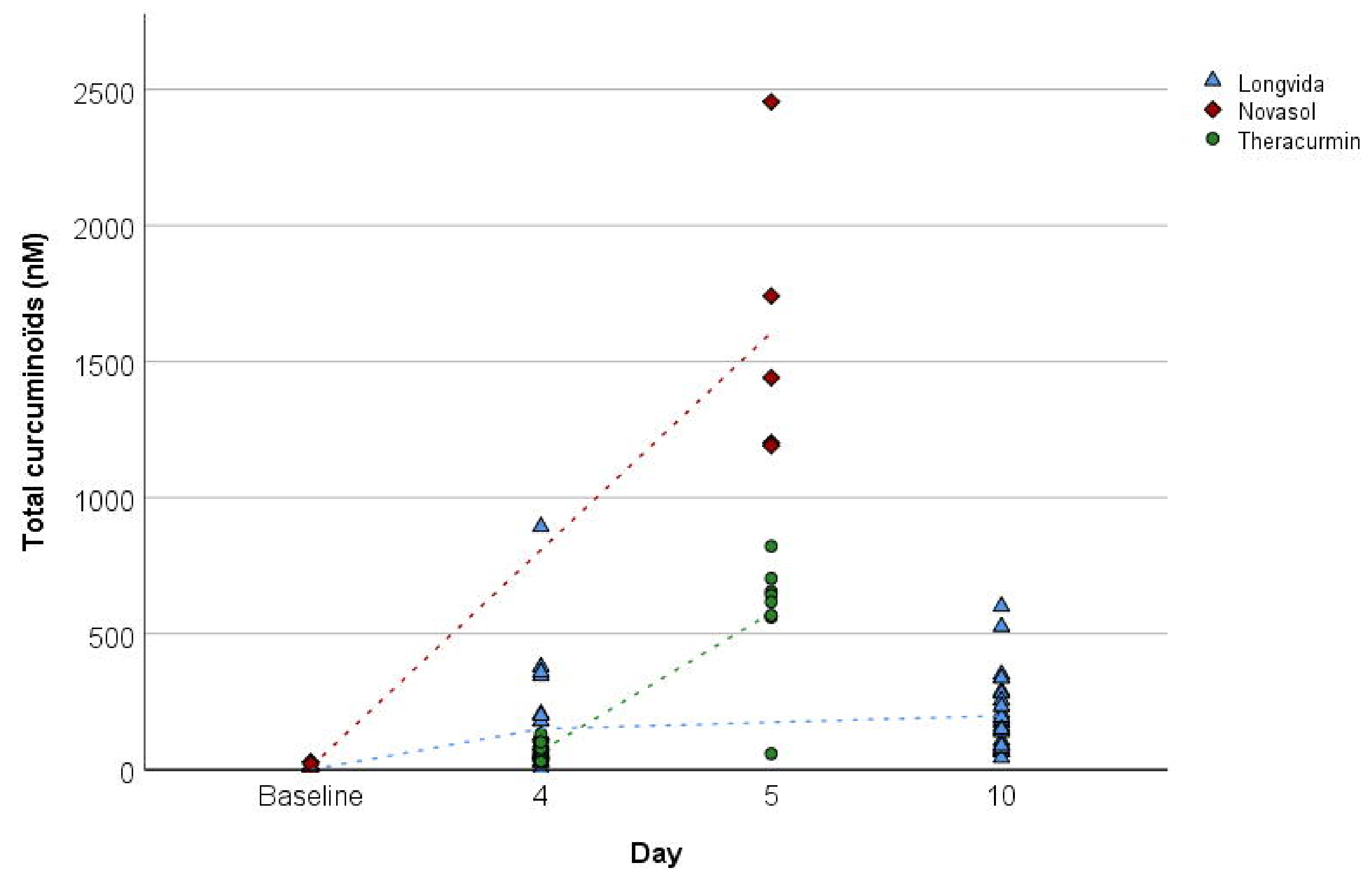

